\title{
АНАЛІЗ ОСНОВНИХ ТРЕНДІВ РОЗВИТКУ РИНКУ ГОТЕЛЬНИХ ПОСЛУГ
}

Погасій С. О., канд. техн. наук, доцент

Краснокутська Ю. В. канд. екон. наук, доцент

Нікітіна І. В., магістрант

Харківський національний університет міського господарства імені О.

\section{М. Бекетова}

Постановка проблеми. Розвиток інтеграційних процесів в економіці та посилення взаємозв'язків між територіями передбачають високий рівень розвитку сфери послуг як елемента господарського механізму. Перспективи зростання обсягів надання послуг додають цьому сектору привабливості для бізнесу. Аналіз розвитку економічної ситуації на українському ринку та закордонний досвід свідчать про стійкий характер посилення конкуренції в готельному бізнесі. Незважаючи на прискорене впровадження в експлуатацію нових та реконструкцію існуючих готелів, попит на якісні готельні послуги постійно зростає. В цих умовах істотно зростає роль управління готельними організаціями, яке повинне забезпечувати розвиток соціальної інфраструктури ринку, високу ефективність функціонування, конкурентоспроможність та стійке положення на ринку. Динамічність зміним зовнішньої середи, ускладнення бізнес-процесів та зростаюча конкуренція на ринку готельних послуг вимагають від керівників організацій вміння бачити перспективу розвитку та приймати стратегічні рішення, засновані на комплексному та системному підході, на аналізі факторів зовнішньої та внутрішньої середи, ефективному управлінні ресурсами та потенціалом організації.

Аналіз останніх досліджень і публікацій. Питаннями розвитку ринку готельних послуг займались такі вчені: М. Амірова, Г. Амосова, І. Андренко, Д. Боуен, Р. Броймер, Г. Вітавська, В. М. Тупкало, Ю. Я. Опанащук, С. Байлик, Р. Ладиженська, Дж. Мейкенз, І. Балабанов, Ю. Волков, В. Герасименко, В. Гулясв, А. Дурович, І. Зорін, Л. Нечаюк, М. Мальська, Г. Мунін, Г. Папирян, П. Пуцентейло, Х. Роглєв, Н. Телеш, Дж. Уокер, В. Цибух, С. Цьохла, О. Шаблій, А. Шатрова, І. Школа, Л. Шматько та ін.

Невирішені складові загальної проблеми. Незважаючи на велику кількість праць, присвячених функціонуванню готельного господарства, питання аналізу сучасних трендів розвитку галузі та існуючих проблем враховуючи зовнішні впливи на різних рівнях неможливо назвати достатньо розробленими.

Формування цілей статті. Метою дослідження $\epsilon$ дослідження закордонного досвіду розвитку індустрії гостинності, а також вивчення системи факторів, що визначають розвиток ринку готельних послуг на основі вивчення тенденцій та проблем його розвитку.

Виклад основного матеріалу дослідження. Індустрія гостинності історично сформувалася із сектору засобів розміщення, представленого різними 
типами готельних підприємств. Готель - це підприємство, що дозволяє людям, що знаходяться поза місцем свого постійного перебування, комплекс послуг, важливішими 3 яких $є$ послуги розміщення та харчування. Сучасне готельне підприємство надає споживачам не тільки послуги розміщення та харчування, але й широкий спектр послуг зв'язку, розваг, екскурсійне обслуговування, медичні, оздоровчі та спортивні послуги, послуги салонів краси тощо. Фактично готельні підприємства в структурі індустрії туризму та гостинності виконують ключові функції, оскільки формують та пропонують споживачам розширений готельних продукт, в формування та просуванні якого приймають участь усі сектори та елементи індустрії туризму та гостинності.

Сучасні готельні послуги характеризуються наступними особливостями:

- їх якість в значному ступені визначається персоналом готелів, особливо тією їі частиною, яка безпосередньо контактує з туристом;

- продаж готельних послуг залежить не тільки від персоналу готелю, але й від внутрішньої якості готельного господарства (зручностей, матеріальнотехнічної бази), а також іміджу готелю, його місце розташування, навколишнього середовища, наявності транспортних комунікацій, культурноісторичних можливостей регіону, іміджу території та рівня конкуренції;

- попит на готельні послуги мінливий, залежить від пори року та сезонних коливань [1].

На сучасному етапі основними інструментами при формуванні ефективної системи управління готельним комплексом є використання нових технологій (в тому числі Інтернет-технологій), енергоефективність, адаптація до попиту споживачів, багатофункціональність, гнучкість, соціальна та екологічна відповідальність, регулювання операційних витрат. Розвиток мережі Інтернет приносить готельному та туристському бізнесу такі переваги як зниження витрат, зростання ефективності, легкий доступ до споживачів навіть для невеликих компаній. Електронний маркетинг розвивається особливо швидко. Серед останніх тенденцій слід виділити розвиток соціальних мереж. Наразі як готельні, так і туристські компанії приймають участь в просуванні свого продукту через соціальні мережі.

Ефективний готельний менеджмент включає в себе однаковий облік економічних, екологічних та функціональних аспектів, а також капіталовкладень, витрат виробництва та якості процесів разом 3 комфортом, здоров’ям та задоволенням потреб.

Однією $з$ розповсюджених світових тенденцій готельного бізнесу для готелів класів бізнес та люкс $\epsilon$ залучення бізнес-туристів предметами мистецтва. Готельні оператори співпрацюють 3 відомими галереями та музеями, декоруючи холи, ресторани та номери предметами мистецтва та антикваріату, пропонуючи своїм гостям білети на модні виставки. Деякі готельні комплекси виставляють в своїх приміщеннях унікальні роботи Енді Уорхола, Сальвадора Далі та Пабло Пікассо, а також витворами місцевих художників. Подібна практика спрямована на підвищення лояльності зі сторони клієнтів. 
Наряду 3 залученням бізнес-туристів витворами мистецтва, розповсюдженою світовою практикою з просування готельних послуг преміумкласу $є$ концентрація на вузькому сегменті клієнтів для створення оригінального готельного продукту. Наприклад, по всьому світу зростає кількість готелів Women Only. Перший подібний готель Barbizon Hotel for Women 3'явився на початку XX ст. в Нью-Йорку. Цей готель «тільки для жінок» повинен був сприйматися як символ фемінізму. 3 80-х рр. радикальні правила було пом'якшено, в готелі розміщувалися усі бажаючі. На сьогодні цей готель внесено до Національного реєстру історичних місць США [2].

Слід відмітити, що одне 3 найбільш значущих жіночих вимог - гарантія абсолютної чистоти та гігієнічності. Деяким жінкам, що залишаються в готелі, необхідно знати, що до них в номері жили виключно жінки та убирати номер також тільки жінки. Враховуючі ці побажання в готелі Bella Sky Comwell (Копенгаген) відкрили поверх виключно для дам 3 великими душовими кімнатами, міні-барами 3 шампанським, шоколадом та коктейлями, а також багатьма додаткових елементів вжитку. Інший варіант рішення питання гігієни пропонується готелем Lady's First Hotel (Цюрих). Розташований в будівлі XIX ст. приймає усіх, однак SPA-салон є особливою територією, відвідування якої дозволяється лише жінкам.

Вивчення думок та ідей гостей призвело до початку змін в готелях, завдяки яким гості можуть отримувати послуги з урахуванням індивідуальних потреб. Оскільки жінки стають все більше подорожувати, мережа Нуаtt сфокусувалася на створенні умов, враховуючи саме ці інтереси. Так, вони запустили програму «У Нyatt це є», завдяки якій в готелі можна взяти напрокат або придбати усі необхідні предмети туалету або ужитку. Незважаючи на те, що нові послуги обумовлені потребами жінок, усі гості можуть використовувати переваги від нововведення.

Сучасний ринок готельних послуг знаходиться в постійній динаміці, відповідаючи на запити клієнтів. Бізнес-туристи, яким необхідно зняти номер на декілька годин протягом дня, призвели до виникнення на ринку нової послуги - денних готелів. Ділові люди, що приїхали в інше місце, мають потребу привести себе в порядок перед важливою зустріччю або просто відпочити після тривалого перельоту, а потім залишити готель. Вже багато років таку послугу пропонують готелі при аеропортах, але наразі цю ідею було розповсюджено серед міських готелів. Денних гостей зазвичай просять виїхати до 18-19.00 для того, щоб встигнути підготувати номери до вечірнього в’їзду наступних гостей. При цьому гість сплачує не погодинно, а фіксовану вартість номеру за день. Незважаючи на те, що таку послугу пропонують багато готелів, а також крупних готельних мереж, на інтернет-сайтах засобів розміщення можливість денного розміщення не афішується. Деякі готелі також пропонують використовувати готельні номери в якості тимчасових офісів або для зберігання багажу.

Альтернативний варіант бюджетного та короткотривалого розміщення в мегаполісах пропонують туристам капсульні готелі, які вперше з'явилися в 
Японії (Осака) в 1979 р. Капсульні готелі складаються з невеликих за площею номерів. Простір в готелі поділяється на два типи: громадське та індивідуальне. Загальною вимогою капсульних готелів такого типу $є$ великий громадський простір. Хол, кімната відпочинку, бар, сауна, басейн, існують для спілкування. Інтер'єр капсул в усіх готелях витримано в карамельному кольорі, що заспокійливо діє на нервову систему людини, яка знаходиться в маленькому закритому просторі.

Початкова японська концепція капсульних готелів зазнала змін в сторону покращення, сьогодні в капсульних готелях зупиняються респектабельні туристи. При чому основною метою візиту для японців в капсульний готель $\epsilon$ відвідування онсену - оздоровчого центру, оснащеного великими ваннами 3 гарячою водою.

В Європі ідея «капсул для життя» трансформувалася із мінімалістичної в дизайнерську. Свропейські капсульні готелі, на відміну від японських готелів даного типу, схожі не на капсули, а на каюти сучасних круїзних лайнерів. Таким чином, капсульний готель стає прямим конкурентом хостелів, які складаються з багатомісних номерів. За думкою маркетологів, приймаючи до уваги вартість розміщення, в Європі у капсульних готелів $є$ перспективи.

Слід відмітити, що поява великої кількості бюджетних готелів у світі пов'язаний 3 розвитком дешевих авіаперевезень (Low Cost): незаможні пасажири перетворилися в потенційних туристів. При цьому задовільними запити кліснтів 3 невеликим статком можливо тільки двома способами: або звести до мінімуму набір послуг, або максимально зменшити площу номеру.

Разом 3 капсульними готелями до готелів з унікальною концепцією та дизайном слід віднести й Bubble-готелі. У місці Руб (Франція) 3'явився ряд прозорих палаток, призначених для проживання та відпочинку туристів. Новий шарообразний готель, що нагадує мильний пузир, відкрито й на околиці Парижу. Це місце приваблює подорожуючих спокійним та затишним розташуванням, що дозволяє відчути себе ближче до природи, далеко від міста та суєти. В якості основної ідеї для відкриття подібного готелю стало намагання дизайнеру створити місце для сучасного відпочинку. Проект нового готелю грунтується на наступних принципах: мінімум енергії, мінімум матеріалу, максимальний комфорт та максимальний вплив на оточуюче середовище.

Усі ці характеристики дозволяють готелю претендувати на звання екологічного готелю, заснованого на принципах бережного відношення до природи та оптимального використання іiі ресурсів. Таке відношення споживачів стимулює готелі до розвитку технологій роботи, що не наносять шкоди навколишньому середовищу або в значному ступені знижують його. Все частіше в засобах масової інформації з'являються дані про те, що представники верхнього цінового готельного сегменту проявляють ініціативну в даному напрямку та зосереджують свої зусилля на екології.

Якщо раніше готельна сфера було орієнтовано переважно на туристів, які диктували готелям умови роботи, то сьогодні ставка робиться на представників 
бізнесу - як крупного, так і невеликого. Їх вимоги до комфортного розміщення навіть на порядок вище, ніж у туристів, оскільки готель для ділової людини це не тільки місце проживання, але й місце роботи. Саме тому сучасні готелі все частіше пропонують своїм гостям організацію бізнес-конгресів, зали для прес-конференцій, допомогу в організації переговорів 3 кліснтами та партнерами. Для цих цілей створюються не тільки конференц-зали, але й лобібари та просто вестибюлі, де можливо організувати кофе-брейк. При цьому ділові готелі ще й обирають особливе розташування, зручне з точки зору транспортних розв'язок.

Інші тенденції готельного бізнесу враховують намагання все більшої кількості гостей вести здоровий образ життя. Саме тому багато готелів роблять ставку на відкриття басейнів, фітнес-центрів та СПА. Більш того, в багатьох 3 них відкриваються додаткові ресторани (або створюється додаткове меню) 3 дієтичними блюдами. Також широко розповсюджено відкриття ресторанів 3 національною кухнею. Національне питання дуже важливе - сучасні готел'єри намагаються враховувати його, розміщаючи гостей: в залежності від вподобань тієї чи іншої нації пропонуються номери з певним температурним режимом, особливим меблюванням, наявністю тих чи інших предметів, що відповідають культурі гостя. Найбільш яскрава тенденція на сучасному ринку - появлення бутік-готелів. Це особливі готелі з акцентом на ексклюзивність, які мають безліч дивовижних особливостей - наприклад, кімнати мають не номери, а назви, меблі групуються за кольорами, в номерах $є$ власний обслуговуючий персонал, який працює тільки на конкретних гостей тощо.

Провідними лідерами готельної індустрії вважаються Італія, Німеччина, Франція, Іспанія, Англія, Австрія, Греція, Швейцарія. Аналіз досвіду розвитку європейської готельної індустрії дозволяє виявити наступні особливості:

- поглиблення спеціалізації готельних підприємств;

- створення і зростання міжнародних готельних мереж;

- активне використання інформаційних технологій;

- розвиток електронної комерції в індустрії гостинності;

- політика збереження навколишнього середовища.

Саме для європейських готелів $\epsilon$ характерними значні інвестиції в енергозберігаючі технології і послуги. Такі інвестиції здійснюються завдяки зростанню вартості енергії, запровадженню додаткових екологічних вимог, збільшенню очікувань клієнтів, технічним досягненням тощо. Європейський ринок готельних послуг наразі знаходиться в постійній динаміці, відповідаючи на нові запити гостей [3].

Розвиток масового туризму, в першу чергу внутрішнього туризму, породжує попит на засоби розміщення, розташовані ближче до привабливих об'єктів (заміські готелі, приватні пансіонати, туристичні села тощо). Масовий туризм і його розвиток обумовлюється насамперед внутрішнім туризмом у кожній із країн, а кількість міжнародних подорожей на порядок менше кількості внутрішніх подорожей. Відповідно це відображується у зростанні попиту на дешевші готельні місця в кожній країні. 
Різноманітність інтересів та потреб інших мандрівників породжує попит на засоби розміщення інших типів засобів розміщення, таких як готелі для спортивного туризму, спеціалізовані готелі, в т.ч. мотелі. Державна підтримка індустрії гостинності є одним з міцніших важелів впливу на розвиток готельних послуг. В Туреччині готельно-туристський комплекс на 40\% датується державою, що дозволяє встановлювати конкурентоспроможні ціни. Крім того, прийнятий зручний для туристів вільний обіг іноземної валюти разом 3 місцевою. В Ізраїлі до 30\% інвестицій в готельну сферу повертається інвестору державою у вигляді прямих відрахувань та податкових пільг за умови досягнення певних обсягів залучення туристів. В Мексиці створені зони франко, вільні від оподаткування, біля відомих курортів Акапулько та Канкун.

В Іспанії прийнятий план підвищення конкурентоспроможності іспанського турпродукту, де в якості пріоритетного напрямку виділені реконструкція та модернізація готелів в основних курортних зонах, розвиток сільського туризму в районах, що не мають доступу до пляжів (Валенсія). Острів Тенерифе оголошено зоною франко, що не тільки знижує ціни на туристські послуги (в тому числі готелів), але й відображується на вартості інших продуктів, зокрема, бензину. Уряд інвестує великі кошти в розвиток інфраструктури острову. В Марокко прийнято план розвитку туризму, що передбачає бюджетні інвестиції (20-40\%) в пріоритетні проекти розвитку (крупні парки розваг, готельні комплекси тощо). В Індонезії острів Балі визнано вільною економічною зоною, що знижує ціни на туристську пропозицію. Також практикуються прямі бюджетні інвестиції в розвиток інфраструктури.

Аналіз закордонного досвіду організації та просування готельних послуг дозволяє виявити наступні тенденції в розвитку галузі:

послуг;

- посилення конкуренції зумовлює необхідність пропозиції нових

- інтеграція готельних підприємств 3 підприємствами інших галузей, що передбачає підвищення різноманіття послуг, що пропонуються;

- масовість, демократизація послуг гостинності, зростання сегменту «бюджетного» відпочинку;

- поглиблення спеціалізації готелів, спрямоване на інтенсифікацію сегментування ринку, диференціацію спектру споживачів;

- глобалізація готельного бізнесу;

- розвиток автоматизації робочого процесу;

- зростаюча увага до якості (багато категорійних засобів розміщення намагається не тільки відповідати вимогам галузевих стандартів, а й розробляють власні системи управління якістю);

- посилення маркетингових зусиль у просуванні готельних послуг;

- підвищена увага до факторів безпеки та попередження виникнення форс-мажорних обставин в засобах розміщення [4].

Розвиток готельного господарства має велике значення для забезпечення високого рівня зайнятості, позитивного впливу на функціонування суміжних секторів державної економіки. Крім того, активізація підприємництва в 
індустрії гостинності сприяє вільному доступу до міжнародного інвестиційного капіталу, поглиблення інтеграції в світову економічну систему.

Особливостями та тенденціями розвитку готельного господарства в теперішній час є наступні:

- дестабілізація зовнішньої середи готельного бізнесу у зв'язку зі зміною суспільно-економічної ситуації;

- зниження ефективності традиційних заходів державного регулювання готельного бізнесу у зв'язку з низьким рівнем координації та системності управлінських рішень та надмірним ступенем їх централізації;

- урахування інтересів переважно крупних учасників ринку при розробці та реалізації заходів державного регулювання сфери готельного бізнесу, в області стандартизації;

- зростання конкурентної боротьби за клієнта, що призводить до розвитку готельних мереж, франчайзингу, а також ускладнення зовнішньої середи діяльності підприємств малого готельного бізнесу;

- суперечливі тенденції розвитку організаційних форм готельного бізнесу, пов'язані, 3 одного боку, 3 експансією крупних підприємств, інтеграційними процесами при розвитку мережевих та франчайзингових форм взаємодії; з іншого боку, з підвищенням значущості індивідуалізації послуг та зростанням затребуваності діяльності малих підприємств;

- всебічна інформатизація процесів надання готельних послуг, перетворення інформації у важливіший ресурс діяльності, який дозволяє отримати конкурентні переваги;

- ускладнення процесів надання послуг, пов'язане зі зростання різноманіття потреб в готельних послугах, а також супутніх послуг, та кількості суб' єктів, що приймають участь в їх надання;

- глобалізація процесів надання готельних послуг, що зумовлює можливість передачі інформації на великі відстані без прив'язки до конкретного місця надання послуги $[5,6,7]$.

Впливаючи на функціонування різних сфер суспільного життя, готельне господарство суттєво залежить як від міжнародних, так i національних чинників різного рівня впливу. Тобто формування й ефективність реалізації потенціалу галузі залежить від умов і тенденцій навколишнього середовища, для якого притаманні складність, невизначеність і важка прогнозованість, що часто призводить до кризових явищ [8].

Висновки 3 проведеного дослідження. Розвиток готельного господарства стримується рядом проблем, причини та прояви яких виникають на різних рівнях господарювання: макро-, мезо- та мікрорівнях.

Сукупність обмежень в залежності від рівня їх впливу включає:

- національні (проявляються на макрорівні: наявність застарілих стандартів, що не відповідають світовим нормам, рівень інвестиційної привабливості галузі та країни);

- територіальні (проявляються на мезорівні: експансія закордонних більш конкурентоспроможних готелів); 
- приватні (проявляються на мікрорівні: дефіцит кваліфікованих кадрів, неготовність до формування та розвитку готельних комплексів, маркетингових та управлінських труднощів, відсутність мотивації до підвищення ефективності функціонування немережевих готелів) [9].

Результати дослідження тенденцій розвитку готельної галузі показали, що iii ефективність значною мірою залежить від зовнішніх чинників функціонування галузі. Для успішного розвитку готельного господарства України необхідна реалізація наступних заходів: удосконалення нормативноправової бази у відповідності до міжнародних вимог до засобів розміщення; формування регіональних програм розвитку готелів; розвиток туристської інфраструктури; формування гнучкої системи стимулювання розвитку готельного бізнесу; посилення ролі саморегулювання в сфері готельного господарства; створення можливостей для будівництва та роботи малих готелів; створення сприятливих умов для залучення інвестицій.

Однак в ряді випадків в сучасних умовах українським готелям необхідні ресурси та продуманість маркетингової політики для досягнення ефективного управління готельним бізнесом. Реалізація запропонованих заходів сприятиме підвищенню конкурентоспроможності готельного господарства України на міжнародному ринку готельних послуг.

\section{Перелік посилань}

1. Ткаченко Т. Управление качеством гостиничных услуг: методологические и практические аспекты. Гостиничный $и$ ресторанныцй бизнес. 2005. №7. С. 24-27.

2. Fyfe D. A., Holdsworth D. W. Signatures of commerce in small-town hotel guest registers. Social science history. 2009. Vol. 33. No 1. P. 17-45.

3. Сучасні тенденції розвитку готельно-ресторанного бізнесу: міжнародний та національний досвід : колективна монографія / за заг. ред. А. Ю. Парфіненка. Харків: ХНУ імені В. Н. Каразіна, 2017. С. 75-86.

4. Орлова О. М. Актуальні проблеми готельно-туристичного бізнесу в України. Бізнес-інформ. 2007. №1. С. 153-159.

5. Єрмаченко В. С., Журавльова С. М. Стратегії розвитку підприємств готельного господарства. Молодий вчений. 2015. № 5(1). С. 138-141.

6. Опанащук Ю. Я. Развитие гостиничного хозяйства в Украине: тенденции и перспективы. Гостиничный и ресторанный бизнес. 2004. № 3. С. $70-72$.

7. Скобєлєва Г. С., Єлісєєнко О. В. Сучасний стан та перспективи розвитку готельного господарства України. Вісник Бердянського університету менеджменту $і$ бізнесу. 2015. № 4. С. 45-48.

8. Смольнякова Н. М., Волосов А. М. Тенденції формування та реалізації економічного потенціалу вітчизняного готельного господарства. Економічна стратегія і перспективи розвитку сфери торгівлі та послуг. 2011. Вип. 1. C. 340-348.

9. Погасій С. О., Стешенко О. Д., Краснокутська Ю. В. Проблеми та перспективи розвитку готельного господарства України. Збірник наукових 
праць Харківського національного автомобільно-дорожнього університету. 2017. №3 (18), том 1. С. 92-97.

\section{References}

1. Tkachenko, T. (2005), Quality management of hotel services: methodological and practical aspects [Upravlenie kachestvom gostinichnykh uslug: metodologicheskie i prakticheskie aspekty], Hotel and restaurant business, No 7, P. 24-27.

2. Fyfe, D. A., Holdsworth, D. W. (2009), Signatures of commerce in smalltown hotel guest registers, Social science history, No 33, No 1, P. 17-45.

3. Parfinenko, A. Iu. (2017), Modern trends in hotel business: international and national experience: monograph [Suchasni tendencziyi rozvitku gotelno-restorannogo biznesu: mizhnarodnij ta naczionalnij dosvid: monografiia], V. N. Karazin KNU, Kharkiv, P. 75-86.

4. Orlova, O. M. (2007), Actual problems of tourism business in Ukraine [Aktualni problemi gotelno-turistichnogo biznesu v Ukrayini], Business-inform, No 1, P. 153-159.

5. Iermachenko, V. I., Zhuravlev, S. M. (2015), Development strategy of enterprises of hotel economy [Strategiyi rozvitku pidpriyemstv gotel`nogo gospodarstva], Young scientist, No 5(1), P. 138-141.

6. Opanashuk, Iu. Ia. (2004), Development of the hotel industry in Ukraine: trends and prospects [Razvitie gostinichnogo khozyajstva $\mathrm{v}$ Ukraine: tendenczii $\mathrm{i}$ perspektivy], Hotel and restaurant business, No 3, P. 70-72.

7. Skobeleva, G. S., Eliseenko, O. V. (2015), Current state and prospects of development of hotel economy of Ukraine [Suchasnij stan ta perspektivi rozvitku gotelnogo gospodarstva Ukraini], Bulletin of Berdyansk University of management and busines, No 4, P. 45-48.

8. Smolnyakova, N. M. Volosov, A. M. (2011), Tendencies of formation and realization of economic potential of the domestic hotel industry [Tendencziyi formuvannya ta realizacziyi ekonomichnogo potenczialu vitchiznyanogo gotelnogo gospodarstva], Economic strategy and prospects of development of sphere of trade and services, No 1, P. 340-348.

9. Pohasii, S. O., Steshenko, O. D., Krasnokutska, Iu. V. (2017), Problems and prospects of development of hotel economy of Ukraine [Problemi ta perspektivi rozvitku gotelnogo gospodarstva Ukrayini], Scientific works of the Kharkiv national automobile and highway University, No 3 (18), tom 1, P. 92-97.

\section{РЕФЕРАТИ РЕФЕРАТЫ ABSTRAСТS}

\section{УДК 338.46:640.4, JEL Classification: L 830}

Погасій С. О., Краснокутська Ю. В. Нікітіна І. В. АНАЛІЗ ОСНОВНИХ ТРЕНДІВ РОЗВИТКУ РИНКУ ГОТЕЛЬНИХ ПОСЛУГ

Mema дослідження $\epsilon$ дослідження закордонного досвіду розвитку індустрії гостинності, а також вивчення системи факторів, що визначають розвиток ринку готельних послуг на основі вивчення тенденцій та проблем 
його розвитку. Методика дослідження. Використано методи порівняння та аналогій при виявленні основних трендів розвитку готельного господарства. Аналіз тенденцій розвитку галузі показав, що ії ефективність значною мірою залежить від зовнішніх чинників функціонування галузі. Було узагальнено основні напрямки реалізації заходів для успішного розвитку готельної індустрії України. Результати дослідження. Виявлено проблеми розвитку готельного господарства, а також існуючі обмеження в залежності від рівня їх впливу на функціонування галузі. Розроблена низка заходів для успішного розвитку готельного господарства України. Наукова новизна. Запропоновано заходи для успішного розвитку готельного господарства України: удосконалення нормативно-правової бази у відповідності до міжнародних вимог до засобів розміщення, формування регіональних програм розвитку готелів, розвиток туристської інфраструктури, формування гнучкої системи стимулювання розвитку готельного бізнесу, посилення ролі саморегулювання в сфері готельного господарства, створення можливостей для будівництва та роботи малих готелів, створення сприятливих умов для залучення інвестицій, що дозволить підвищити конкурентоспроможність готельного господарства України на міжнародному ринку готельних послуг. Практична значущість полягає у можливості використання вітчизняними підприємствами сфери готельно-ресторанного бізнесу провідного закордонного досвіду функціонування підприємств готельного господарства та впровадження інновацій в їх діяльність.

Ключові слова: готельне господарство; тенденції розвитку; ринок готельних послуг.

\section{УДК 338.46:640.4, JEL Classification: L 830}

Погасий С. А., Краснокутская Ю. В. Никитина И. В. АНАЛИЗ ОСНОВНЫХ ТРЕНДОВ РАЗВИТИЯ РЫНКА ГОСТИНИЧНЫХ УСЛУГ

Цель исследования заключается в исследовании зарубежного опыта развития индустрии гостеприимства, а также изучение системы факторов, определяющих развитие рынка гостиничных услуг на основе анализа тенденций и проблем его развития. Методика исследования. Использованы методы сравнения и аналогий при выявлении основных трендов развития гостиничного хозяйства. Анализ тенденций развития отрасли показал, что ее эффективность в значительной степени зависит от внешних факторов функционирования отрасли. Обобщены основные направления реализации мероприятий для успешного развития гостиничной индустрии Украины. Результаты исследования. Выявлены проблемы развития гостиничного хозяйства, а также существующие ограничения в зависимости от уровня их влияния на функционирование отрасли. Разработан ряд мероприятий для успешного развития гостиничного хозяйства Украины. Научная новизна. Предложены мероприятия для успешного развития гостиничного хозяйства Украины: усовершенствование нормативно-правовой базы в соответствии с международными требованиями к средствам размещения, формирование 
региональных программ развития гостиниц, развитие туристической инфраструктуры, формирование гибкой системы стимулирования развития гостиничного бизнеса, усиления роли саморегулирования в сфере гостиничного хозяйства, создание возможностей для строительства и работы малых отелей, создание благоприятных условий для привлечения инвестиций, что позволит повысить конкурентоспособность гостиничного хозяйства Украины на международном рынке гостиничных услуг. Практическая значимость заключается в возможности использования отечественными предприятиями сферы гостинично-ресторанного бизнеса ведущего зарубежного опыта функционирования предприятий гостиничного хозяйства и внедрение инноваций в их деятельность.

Ключевые слова: гостиничное хозяйство; тенденции развития; рынок гостиничных услуг.

\section{UDC 338.46:640.4, JEL Classification: L 830}

\section{Pohasii S., Krasnokutska Iu., Nikitina I. THE ANALYSIS OF THE MAIN TRENDS OF THE DEVELOPMENT OF HOTEL SERVICES MARKET}

The purpose of the research is to study the foreign experience in the development of the hospitality industry, as well as the study of the factors determining the development of the market of hotel services on the basis of analyzing tendencies and problems of its development. Methodology of the research. The methods of comparison and analogies have been used when identifying the main trends in the development of the hotel industry. Analysis of trends showed that its effectiveness largely depends on external factors of functioning of the industry. It generalizes main directions of implementation measures for the successful development of the hotel industry of Ukraine. Findings. The problems of development of the hotel industry have been identified, as well as current limitations depending on the level of their influence on the functioning of the sector. Developed a number of activities for the successful development of the hotel industry of Ukraine. Originality. The activities for the successful development of the hotel industry of Ukraine have been offered: improvement of normative legal base in accordance with international standards for accommodation facilities, the formation of regional programs of development of hotels, development of tourism infrastructure, the formation of a flexible system of promoting development of hotel business, to strengthen the role of self-regulation in the sphere of hospitality industry, creating opportunities for the construction and operation of small hotels, creation of favorable conditions for attracting investments that will enhance the competitiveness of hotel economy of Ukraine on the international hotel market. Practical value comprises the possibility of usage for domestic enterprises of the sphere of hotel and catering business of the leading foreign experience of functioning of enterprises of hotel economy and innovation in their activities.

Key words: hotel industry; trends of development; hotel services market. 


\section{Відомості про авторів / Сведения об авторах / About the Authors}

Погасій Сергій Олександрович - кандидат технічних наук, доцент, Харківський національний університет міського господарства імені О. М. Бекетова, доцент кафедри туризму і готельного господарства, м. Харків, Україна; e-mail: POHASII07@gmail.com; ORCID ID: https://orcid.org/0000-0001-7241-1237. Моб. 050-747-40-65.

Погасий Сергей Александрович - кандидат технических наук, доцент, Харьковский национальный университет городского хозяйства имени А. Н. Бекетова, доцент кафедры туризма и гостиничного хозяйства, г. Харьков, Украина.

Pohasii Serhii - Candidate of Sciences (Technical Sciences), Associate Professor, O. M. Beketov National University of Municipal Economy in Kharkov, Associate Professor at the Department of Tourism and Hospitality Management, Kharkiv, Ukraine.

Краснокутська Юлія Вадимівна - кандидат економічних наук, доцент, Харківський національний університет міського господарства імені О. М. Бекетова, доцент кафедри туризму і готельного господарства, м. Харків, Україна; e-mail: y0506180284@gmail.com; ORCID ID: https://orcid.org/00000001-7241-1237. Моб. 050-618-02-84.

Краснокутская Юлия Вадимовна - кандидат экономических наук, доцент, Харьковский национальный университет городского хозяйства имени А. Н. Бекетова, доцент кафедры туризма и гостиничного хозяйства, г. Харьков, Украина.

Krasnokutska Iuliia - Candidate of Sciences (Economics), Associate Professor, O. M. Beketov National University of Municipal Economy in Kharkov, Associate Professor at the Department of Tourism and Hospitality Management, Kharkiv, Ukraine.

Нікітіна Ірина Вячеславівна - магістрант, Харківський національний університет міського господарства імені О. М. Бекетова, магістрант кафедри туризму і готельного господарства, м. Харків, Україна;. Моб. 099-008-15-43.

Никитина Ирина Вячеславовна - магистрант, Харьковский национальный университет городского хозяйства имени А. Н. Бекетова, магистрант кафедры туризма и гостиничного хозяйства, г. Харьков, Украина.

Nikitina Iryna - undergraduate, O. M. Beketov National University of Municipal Economy in Kharkov, undergraduate at the Department of Tourism and Hospitality Management, Kharkiv, Ukraine. 